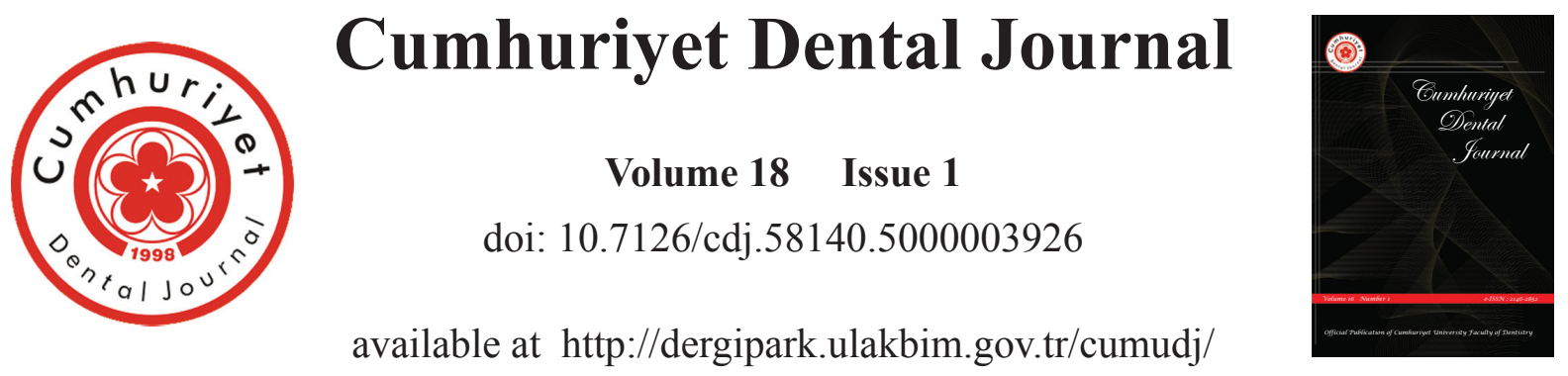

CASE REPORT

\title{
Apexification of a dens evaginated premolar with open apex
}

Mariana Comparotto Minamisako, DDS, ${ }^{a}$ Jun-Ichiro Kinoshita, $P h D, D D S,{ }^{b}$

Liliane J. Grando, DDS, MSc, ${ }^{c}$ Hamid Jafarzadeh, DDS, MSc, ${ }^{d}$

${ }^{a}$ Department of Pathology, Health Science Center, Federal University of Santa Catarina, Campus Bairro Trindade,

Florianópolis, Santa Catarina State, Brazil

${ }^{b}$ Department of Conservative Dentistry, Showa University School of Dentistry, Tokyo, Japan

'Department of Pathology, Health Science Center, Federal University of Santa Catarina, Campus Bairro Trindade,

Florianópolis, Santa Catarina State, Brazil

${ }^{d}$ Dental Research Center, Department of Endodontics, Faculty of Dentistry, Mashhad University of Medical Sciences,

Mashhad, Iran

A R T I C L E I N F O

Article history:

Received 31 January 2014

Accepted 05 May 2014

\section{A B S T R A C T}

This case report describes the treatment of a mandibular premolar with incomplete root formation accompanied by pulp necrosis and periapical pathosis caused by dens evaginatus, in which apexification was successfully achieved with calcium hydroxide.

Keywords:

Open Apex

Dens evaginatus

Apexification

\section{INTRODUCTION}

Dens evaginatus (DE) is a tooth developmental anomaly characterized by the occurrence of an extra cusp, usually found in mandibular premolars. ${ }^{1-3}$ The etiology of DE is not fully understood and is thought to be multifactorial. ${ }^{4}$ Genetic influences can be assumed, ${ }^{5,6}$ although a combination of both genetic and environmental factors is more reasonable. ${ }^{4}$
Hiostologically, it is the result of an abnormal proliferation and folding of a portion of the inner enamel epithelium and subjacent ectomesenchymal cells of the dental papilla into the stellate reticulum of the enamel organ during the bell stage of tooth formation. ${ }^{7}$ The resulting tubercle contains a core of dentin surrounding a pulpal extension, which may be narrow, wide, constricted, an isolated horn, or not present at all. ${ }^{7,8}$

Corresponding author at: Hamid JAFARZADEH, Dental Research Center, Vakilabad Blvd, Mashhad, Iran, P.O. Box: 91735-984, Tel: +98-511-8829501, Fax: +98-511-8829500, E-mail: hamid_j365@yahoo.com \& JafarzadehBH@mums.ac.ir 
The anomalous cusp can even cause occlusal trauma and reversible acute apical periodontitis of the opposing tooth, displacement of the affected tooth, irritation of the tongue during speech and mastication, carious lesions in the developmental grooves delineating the cusp, attrition of the opposing tooth and periodontal problems due to the excessive occlusal forces, and the tooth can lose its blood and nerve supply, resulting in pulp necrosis that can cause periapical pathosis, ${ }^{9,10}$ often before completion of the root formation. ${ }^{11} \mathrm{DE}$ often challenges the practitioner with its frequent early pulpal complications, so it is extremely important to diagnose the case as early as possible. ${ }^{12}$

The prevalence of DE has been reported to be $3 \%$ in Keewatin Eskimo, ${ }^{13} 1 \%$ in Thai, ${ }^{14}$ and $3-6.3 \%$ in Chinese ${ }^{15-18}$ populations. Although the occurrence of DE shows great ethnic group differences, with a higher prevalence among people of Asian descent (including Chinese, Malay, Thai, Japanese, Filipino, and Indian populations) $)^{15}$, clinicians all over the world must be aware of the condition because of the high rate of migration in communities. This case report describes the treatment of a dens evaginated mandibular premolar with incomplete root formation accompanied by pulp necrosis and periapical pathosis.

\section{CASE REPORT}

A 12-year-old girl visited the Endodontic Clinic of Showa University School of Dentistry, Tokyo, Japan, with severe pain in the right second mandibular premolar and a slight swelling on its buccal region, which did not respond to the cold test. Before the patient was referred to the hospital, she had periodically visited by a general dentist but her symptoms did not disappear. The premolar with DE (Fig. 1) had not been noticed until pulp necrosis (Fig. 2), and no prophylactic treatment had been employed. The patient medical history was non-contributory.

Because of the very wide open apex, a treatment option was apexification with endodontic treatment. After obtaining informed consent from the patient's parents, apexification treatment was initiated. A rubber dam was placed, and adequate access to the pulp chamber was made without local anesthesia (Fig. 3). The necrotic pulp was removed, and the canal was cleaned and shaped, and irrigated with $5 \%$ sodium hypochlorite and $3 \%$ hydrogen peroxide. The canal was then filled with calcium hydroxide paste (Calcipex, Nohon Shika Yakuhin, Shimonoseki, Japan), and zinc oxide eugenol cement (Eugedine, Showa Yakuhin, Kako, Tokyo, Japan) was placed in the access opening, and the mucosa on the

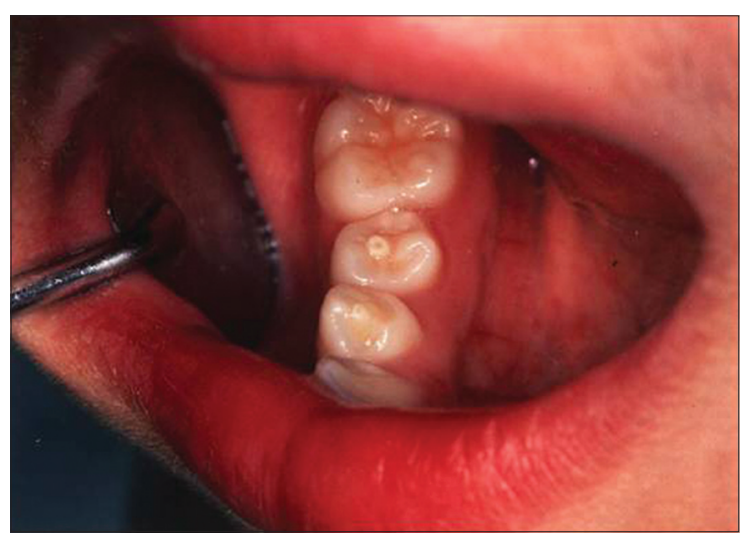

Fig 1. Clinical picture of DE.

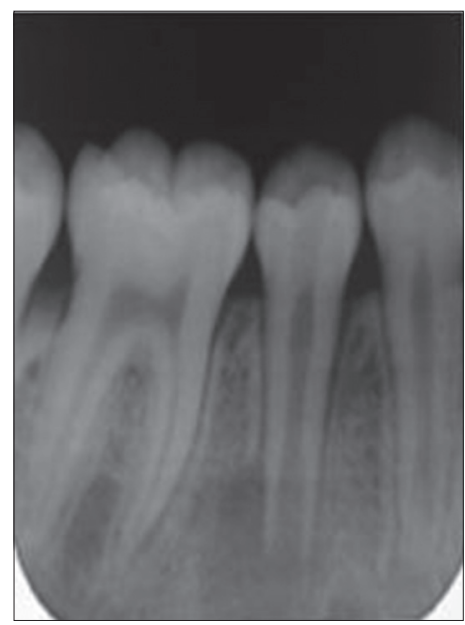

Fig 2. Tooth 45 with pulp necrosis and periapical pathosis. 
apical region of the tooth was irradiated with Nd: YAG laser (Inpulse, Astra Tech, Tokyo, Japan) to reduce postoperative pain. Parameters for laser irradiation were set at $0.4 \mathrm{~W}, 20 \mathrm{~Hz}$ pulse mode, $8 \mathrm{~mm}$ distance, circle movement, five sets of 5 second for each treatment, after endodontic treatment. The patient was recalled every month, and if the calcium hydroxide had absorbed, the canal was filled with calcium hydroxide again.

After 6 months, bone formation was noticed on the radiograph (Fig. 4), and hard dental tissue could be felt with a \#80 K-file (Maillefer, Dentsply, Switzerland) in the root apex, indicating that the root canal was ready to be obturated. The canal was obturated with gutta-percha (Dentsply-Sankin, Tokyo, Japan) rolled up

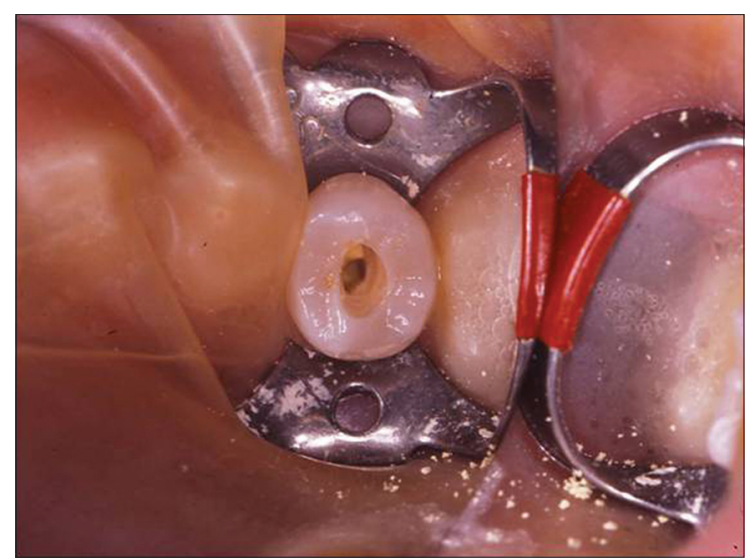

Fig 3. Access to the pulp chamber.

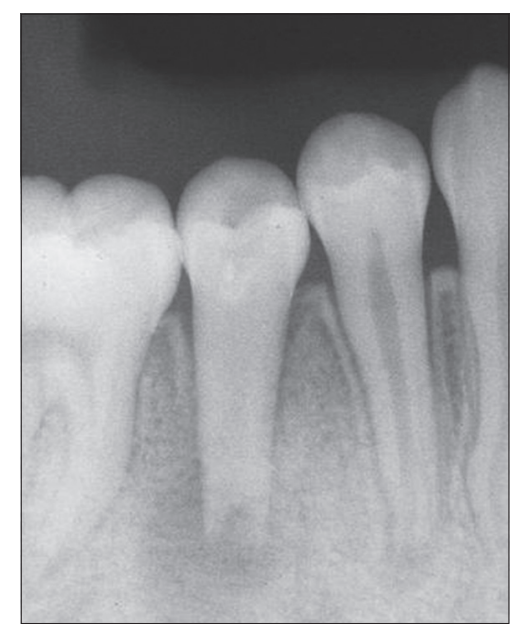

Fig 4. Five months after the first intervention: bone repair can be seen. between two glass-plates, which was used for particularly wide root canals such as in this case, and calcium hydroxide-based sealer (Canals-N, Showa Yakuhin Kako, Tokyo, Japan) was used as the sealer, which overflow outside the apex indicated the complete filling of the root canal (Fig. 5). One month after obturation, the bone repair was considered satisfactory (Fig. 6).

\section{DISCUSSION}

The treatment of DE implicates careful clinical decision. ${ }^{9}$ Since a tooth with

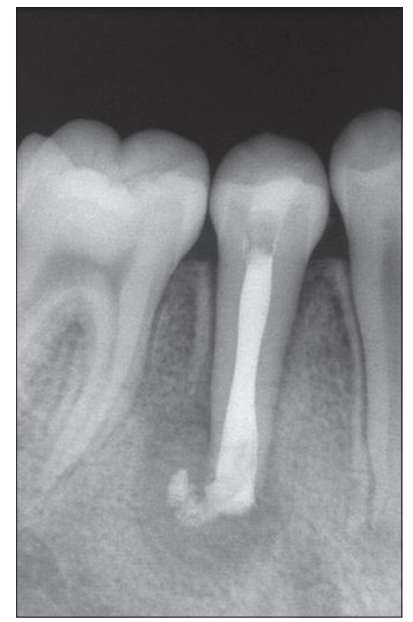

Fig 5. Overflow outside the apex indicates the complete filling of the root canal.

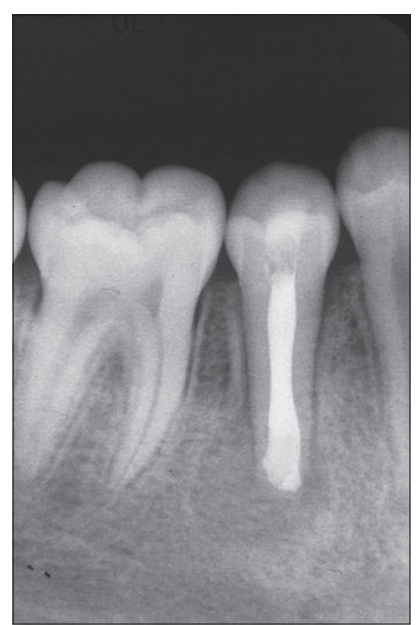

Fig 6. One month after obturation, sealer leakage had resorbed and bone repair was satisfactory. 
DE can lose its blood and nerve supply leading to necrosis of the pulp tissue and even fracture/wear of the tubercle can lead to pulp necrosis before completion of root formation, various prophylactic treatments have been proposed for these teeth. ${ }^{9,19}$ These include selective grinding of the tubercles, ${ }^{1,9,20}$ application of resin to reinforce the tubercles, ${ }^{21,22}$ placement of prophylactic restorations, ${ }^{23}$ or performing partial pulpotomy. ${ }^{11,22}$

Oehler et al. ${ }^{1}$ evaluated the effectiveness of selective grinding of the tubercle and concluded that this treatment was unreliable. Ferraz et al. ${ }^{24}$ reported a case in which a central incisor with talon cusp was grinded for occlusal adjustment, but the tooth remained vital only for 7 months, after which pulp necrosis occurred. On the other hand, other authors have removed large amounts of hard tissues with success. ${ }^{9}$ Segura et al. ${ }^{9}$ successfully reduced $1 \mathrm{~mm}$ of a talon cusp at each appointment, reducing a total of $3 \mathrm{~mm}$ without pulp exposure on a lateral incisor.

Yong ${ }^{25}$ demonstrated that early removal of the $\mathrm{DE}$, accompanied by immediate direct or indirect calcium hydroxide pulp capping and restoration, is effective in maintaining pulp vitality. He successfully treated 39 asymptomatic and vital teeth by removing the tubercles, and placing either direct or indirect pulp capping material followed by amalgam restoration. Lim et al. ${ }^{26}$ performed the same treatment in 121 teeth and reported a $100 \%$ success rate in their study. They compared treatment of DE with either prophylactic amalgam or resin restorations, and a higher success rate was found with the latter treatment. Previous radiographic studies stated that removal of the cusp could inevitably lead to pulp exposure that would require endodontic treatment. ${ }^{27}$

Once symptoms of irreversible pulpitis develop and the diagnosis is confirmed, conventional root canal therapy should be performed followed by placement of an appropriate final restoration. The treatment becomes more complex when pulp inflammation develops because of contamination from the oral cavity when the tooth has an immature apex. In these cases, a shallow pulpotomy using a layer of mineral trioxide aggregate applied to the exposed pulpal surface should be performed. Placement of MTA, as with calcium hydroxide, onto the remaining pulp tissue retains the vitality and function of the pulp-dentin complex, allowing odontoblasts to complete root development for the tooth (i.e. the process of apexogenesis leading to normal thickness of dentinal walls, and increased root length along with apical closure). ${ }^{30}$

Levitan ${ }^{28}$ also said that once the pulp of a tooth with a mature root becomes necrotic, with or without a periapical component, conventional root canal therapy followed by a final restoration is indicated, but if a tooth with a blunderbuss root apex becomes necrotic, with or without periapical component, endodontic therapy is required and the creation of a root end barrier should be considered. Apexification traditionally involved placing calcium hydroxide into the canal of a necrotic immature permanent tooth to induce cells of the apex to create a calcific barrier, but MTA can also be used as an apical barrier for apexification to induce hard tissue formation. ${ }^{29}$ Chen et al. ${ }^{30}$ reported a successful case of apexification in a DE premolar with necrotic pulp and blunderbuss apex in a 20-year-old patient, in which calcium hydroxide was used for 7 months. Cho ${ }^{19}$ also reported successful apexification using calcium hydroxide for 2 years in a premolar with intact $D E$, pulp necrosis and open apex of a 9-year-old patient. The favorable clinical, radiographic and histological responses obtained with calcium hydroxide are attributed to the involvement of $\mathrm{Ca}^{2+}$ and $\mathrm{OH}^{-}$in several cellular and molecular mechanisms leading 
to regeneration of periapical connective tissues. $^{31}$

Parenthetically, extraction may be a treatment choice for patients unable to comply with a possible multi-appointment regimen, or for those young patients with crowded dental arches, and when the loss of the tooth can be included in an orthodontic treatment plan. ${ }^{25}$ In the recent past, for immature affected permanent teeth with either inflamed or necrotic pulps, extraction was the only treatment option. ${ }^{1,13,25}$

Because of DE's frequent and early pulpal complications, it presents a challenge to the dentist. In the present case, successful apexification by calcium hydroxide was achieved.

\section{ACKNOWLEDGMENTS}

This work has been supported in part by: 1) the "High-Tech Research Center" Project for Private Universities: Matching Fund Subsidy from the Ministry of Education, Culture, Sports, Science and Technology (MEXT) of Japan, 2005-2009, received by the Showa University School of Dentistry; and 2) a Grant-in-Aid for Scientific Research (C) (20592336-0010) received by Dr. JunIchiro Kinoshita.

\section{REFERENCES}

1. Oehlers FA, Leek KW, Lee EC: Dens evaginatus (evaginated odontome): its structure and responses to external stimuli. Dent Pract Dent Rec, 17:239-244, 1967.

2. Neville BW, Damm DD, Allen CM, Bonquot JE: Oral and maxillofacial pathology, $2^{\text {nd }}$ ed. Philadelphia: W.B. Saunders Co., 77-79, 2002.

3. Goto $\mathrm{T}$, Kawahara $\mathrm{K}$, Kondo $\mathrm{T}$, Imai K, Kishi K, Fujiki Y: Clinical and radiographic study of dens evaginatus. Dentomaxillofac Radiol, 8:78-83, 1979.

4. Hülsmann M: Etiology and therapy of dens evaginatus. Endodontie, 13:363-372, 2004.

5. Garn SM, Leweis AB, Kerewski RS: Genetic, nutritional and maturational correlates of dental development. J Dent Res, 44:228-242, 1965.

6. Rantanen AV: Talon cusp. Oral Surg Oral Med Oral Pathol Oral Radiol Endod, 32:398-400, 1971.

7. Echeverri EA, Wang MM, Chavaria C, Taylor DL: Multiple dens evaginatus: diagnosis, management, and complications: case report. Pediatr Dent, 16:314-317, 1994.

8. Stecker $S$, DiAngelis A: Dens evaginatus: A diagnostic and treatment challenge. J Am Dent Assoc, 133:190-193, 2002.

9. Segura-Egea JJ, Jimènez-Rubio $A$, Velasco-Ortega E, Rios-Santos JV: Talon cup causing occlusal trauma and acute apical periodontitis: report of a case. Dent Traumatol, 19: 55-59, 2003.

10. Hattab FN, Hazza'a AM: An unusual case of talon cusp on geminated tooth. J Can Dent Assoc, 67:263-266, 2000.

11. Koh ET, Pitt Ford TR, Kariyawasam SP, Chen NN, Torabinejad M: Prophylactic treatment of dens evaginatus using mineral trioxide aggregate. J Endod, 27:540-542, 2001.

12. Uyeno DS, Lugo A: Dens evaginatus: a review. ASDC J Dent Child, 63:328332, 1996.

13. Curzon ME, Curzon JA, Poyton HG: Evaginated odontomes in the Keewatin Eskimos. British Dent J, 129:324-328, 1970.

14. Reichart P, Tantiniran D: Dens evaginatus in the Thai. An evaluation of fifty-one cases. Oral Surg Oral Med Oral Pathology, 39:615-621, 1975.

15. Yip WK: The prevalence of dens evaginatus. Oral Surg Oral Med Oral 
Pathol, 38:80-87, 1974.

16. Bedi R, Pitts NB: Dens Evaginatus in the Hong Kong Chinese population. Endod and Dent Traumatol, 4:104107, 1988.

17. Tsai SJJ, King NM: A catalogue of anomalies and traits of the permanent dentition of southern Chinese. J Clin Pediatr Dentistry, 22:185-194, 1998.

18. Cho SY, Ki Y, Chu V, Chan J: Concomitant developmental dental anomalies in Chinese children with dens evaginatus. Intern $\mathrm{J}$ of Pediatr Dentistry, 16:247-251, 2006.

19. Cho SY: Dental abscess in a tooth with intact dens evaginatus. Intern $\mathrm{J}$ Pediatric Dentistry, 16:135-138, 2006.

20. Hattab FN, Yassin OM, al Nimri KS: Talon cusp in permanent dentition associated with other dental anomalies: review of literature and reports of seven cases. ASDC J Dent Child, 63:368-376, 1996.

21. Kawata T, Tanne K: Early detection of dens evaginatus appearing on the premolars and clinical management: histological study. J Clin Pediatric Dentistry, 26:199-201, 2002.

22. Augsberger RA, Wong $\mathrm{T}$ : Pulp management in dens evaginatus. J Endod, 22:323-326, 1996.

23. Sim TPC: Management of dens evaginatus: evaluation of two prophylactic treatment methods. Endod and Dent Traumatol, 12:137-140, 1996.

24. Ferraz JAB, Carvalho Júnior JR,
Saquy PC, Pécora JD, Sousa-Neto MD: Dental anomaly: dens evaginatus (talon cusp). Braz Dent J, 12:132134, 2001.

25. Yong SL: Prophylactic treatment of dens evaginatus. J Dent Child, 41:289-292, 1974.

26. Lim ST, Yong SL, Chen ML: A review of the prophylactic treatment of dens evaginatus. J Intern Assoc Dentistry for Child, 13:21-25, 1982.

27. Mellor JK, Ripa LW: Talon cusp: a clinically significant anomaly. Oral Surg Oral Med Oral Pathol, 29:225228, 1970.

28. Levitan ME, Himel VT: Dens evaginatus: literature review, pathophysiology, and comprehensive treatment regimen. J Endod, 32:1-9, 2006.

29. Shabahang S, Torabinejad M, Boyne $P$, Abedi H, McMillan P: Apexification in immature dog teeth using osteogenic protein-1, mineral trioxide aggregate, and calcium hydroxide. J Endod, 25:1-5, 1999.

30. Chen CM, Lee KT, Chuang FH, Hong YY, Chen HC, Hsu KR, Wu YM, Lee HE: Facial cellulitis arising from dens evaginatus: a case report. Kaohsiung J Med Sci, 21:333-336, 2005.

31. Soares JA, Santos SMC, Silveira FF, Nunes E: Nonsurgical treatment of extensive cyst-like periapical lesion of endodontic origin. Int Endod J, 39:566-575, 2006.

How to cite this article: Mariana Comparotto Minamisako, Jun-Ichiro Kinoshita, Liliane J. Grando, Hamid Jafarzadeh. Apexification of a Dens Evaginated Premolar with Open Apex. Cumhuriyet Dent J 2015;18(1):86-91. 